IZA DP No. 97

Irish Migration: Characteristics, Causes and Consequences

Alan Barrett

December 1999 


\title{
Irish Migration: Characteristics, Causes and Consequences
}

\author{
Alan Barrett \\ Economic and Social Research Institute, Dublin, CEPR, London \\ and IZA, Bonn
}

Discussion Paper No. 97

December 1999

\author{
IZA \\ P.O. Box 7240 \\ D-53072 Bonn \\ Germany \\ Tel.: +49-228-3894-0 \\ Fax: +49-228-3894-210 \\ Email: iza@iza.org
}

This Discussion Paper is issued within the framework of IZA's research area Mobility and Flexibility of Labor Markets. Any opinions expressed here are those of the author(s) and not those of the institute. Research disseminated by IZA may include views on policy, but the institute itself takes no institutional policy positions.

The Institute for the Study of Labor (IZA) in Bonn is a local and virtual international research center and a place of communication between science, politics and business. IZA is an independent, nonprofit limited liability company (Gesellschaft mit beschränkter Haftung) supported by the Deutsche Post AG. The center is associated with the University of Bonn and offers a stimulating research environment through its research networks, research support, and visitors and doctoral programs. IZA engages in (i) original and internationally competitive research in all fields of labor economics, (ii) development of policy concepts, and (iii) dissemination of research results and concepts to the interested public. The current research program deals with (1) mobility and flexibility of labor markets, (2) internationalization of labor markets and European integration, (3) the welfare state and labor markets, (4) labor markets in transition, (5) the future of work, (6) project evaluation and (7) general labor economics.

IZA Discussion Papers often represent preliminary work and are circulated to encourage discussion. Citation of such a paper should account for its provisional character. 
IZA Discussion Paper No. 97

December 1999

\title{
ABSTRACT \\ Irish Migration: \\ Characteristics, Causes and Consequences ${ }^{\star}$
}

The purpose of this paper is to review what has been learnt about Irish migration from the work of social scientists, largely economists. For most of its modern history, Ireland has experienced large net outflows. I discuss how the outflow was made up of lower skilled people up until the 1980s but how more recent outflows have contained more highly skilled people. Over time, the outflow has also shown shifts in its gender make-up and in the destinations of those leaving. I review the work that has been done exploring the causes of the outflow. Generally, the low level of economic development in Ireland has been responsible; however, year to year fluctuations in the size of the outflows are associated with relative changes in Irish and British labour market conditions. Finally, I consider the work that has examined the effect of the large-scale outflows. While some have argued that the low level of development was partly a consequence of emigration, other work has shown that emigration helped to improve Irish living standards. I end with the observation that the research agenda is now changing as development, and net inflows, have emerged.

JEL Classification: J15, J61

Keywords: Migration, migration policy

\author{
Alan Barrett \\ Economic and Social Research Institute \\ 4 Burlington Road \\ Dublin 4 \\ Ireland
}

Tel: $353-16671525$

Fax: 353-1 6686231

Email: Alan.Barrett@esri.ie

\footnotetext{
"Presented to a conference entitled "European Migration: What do we know", University of Munich, November 1997.
} 


\section{Introduction}

The topic of migration, or more specifically emigration, has been of enormous importance for Ireland since the early part of the last century. Although the Famine of the late 1840s was the catalyst that prompted the large-scale exodus of the second half of the nineteenth century, O'Rourke (1995) has pointed out that 1.5 million people emigrated from Ireland between Waterloo and the Famine; this was equivalent to a rate of 7 per 1000. However, it was the Famine which generated the outflow which in turn contributed to the population of what is now the Republic of Ireland declining from $6,529,000$ in 1841 to $3,222,000$ at the turn of the century ${ }^{1}$. For much of this century emigration has remained high and the population decline continued until 1961. But even in the 1960s emigration continued and after a decade of unprecedented inflows in the 1970s, net outflows resumed in the 1980s.

In this chapter, we will discuss what has been learnt about the Irish migration experience through the research of economists. The Chapter is organised as follows. In Section 2, we present the most important features of the migration flow from (and to) Ireland. In Section 3, we consider the work that has been undertaken in order to identify the factors that have given rise to the migratory pattern. Section 4 contains a discussion of the work which has sought to look at Irish emigrants in their destinations. Section 5 is taken up with the studies that have asked how the large-scale emigration has affected the economy. In Section 6, we summarise what we know about Irish migration. In addition, we consider how research needs have now changed

\footnotetext{
1 As discussed in O'Rourke (1995), some have argued that the outflow from Ireland would have been as high as it was, even in the absense of the Famine; however, the argument is made strongly by O'Rourke that the Famine did indeed create a discontinuity in the Irish migration experience.
} 
somewhat, in the light of Ireland's recent economic growth and the emergence of population inflows which have accompanied this growth.

\section{The Migration Flow}

In order to begin this examination of research into Irish migration, it is useful to take an overview of population and migration figures going back over the last century. The direction that the research has followed has been motivated by the particular realities of Irish migratory history and so some familiarity with that history will enhance our understanding of the research. In Table 1, we present statistics on population change, the natural increase and net migration for the intercensal periods from 1871 to 1996 , plus the year to April 1997, and some striking points emerge.

\section{Table 1 here}

It can be seen from the table that between 1871 and 1961, Ireland experienced almost continuous population decline. This pattern of decline predates 1871, however; the population of Ireland was $6,529,000$ in 1841 and declined continuously to a low point of 2,818,000 in 1961. What is clear from Table 1 is that this pattern of population decline arose because net migration from the area exceeded the natural increase, apart from a period in the late 1950s, up until the 1960s. And even in the 1960s, while population growth had resumed, net migration was still occurring.

Taking the figures up until the 1970s, it is clear that the research efforts would be directed at different elements of emigration. Given the turnaround in the 1970s and the emergence of net inflows, it might have been the case that efforts would have moved to looking at elements of immigration or return migration. However, with the re-emergence of large-scale outflows in the 1980s, the experience of the 1970s began 
to look like a temporary phenomenon and so emigration maintained its position as the focus of researchers' efforts.

The numbers in Table 1 disguise shifts that have occurred in some dimensions of Irish migration so we will briefly outline a number of these. Much of the discussion has been taken from NESC (1991), O’Gràda and Walsh (1994) and Sexton (1996).

\section{Destination}

With regard to the destinations of Ireland's emigrants, a major shift occurred at the beginning of the 1930s. For much of the last century, the majority of Irish emigrants went to the United States; between 1880 and 1921, 87 percent of emigrants went to the United States whereas only 10 percent went to Britain. The Great Depression reduced the employment opportunities available to emigrants and so the Irish began to go to Britain in greater numbers. It is estimated that by the late 1940 s over 80 percent of the outflow went to Britain and this continued into the 1970s. The proportion going to Britain has dropped since but it was still the main destination for most Irish emigrants in the 1980s. The most recent figures, however, show the British share to have fallen to 44 percent; the shares to other destinations are as follows: rest of the EU, 14 percent; USA, 14 percent; rest of the world, 27 percent (Central Statistics Office 1997) ${ }^{2}$. The dominance of Britain as the destination of Irish emigrants in recent decades is reflected in the research which will be discussed below.

\section{$\operatorname{Sex}$}

\footnotetext{
2 The resumption of sizeable emigration to the United States is partly related to an increase in illegal immigration, especially in the 1980s, and also to the visa lotteries which the United States government have run since the late 1980s. A large number of visas were specifically reserved for Irish nationals in the lotteries. Barrett (1996) presents evidence on the skill levels of the lottery immigrants relative to other immigrants for Ireland and eight other countries.
} 
If ones takes a long term look at Irish migration, there appears to be a balance across the sexes in terms of numbers emigrating. However, during certain sub-periods, there were notable imbalances between the sexes, as can be seen from Table 2 .

\section{Table 2 here}

In the late nineteenth century the numbers of males and females in the net outward flow was about equal. But in the twentieth century there were some interesting imbalances. In the period 1936-46, the net outflow was mainly male and this can probably be explained by the nature of the opportunities which arose during the war. Immediately after this period, females were the dominant group in the net outflow; this was probably related to the fact that many women may have delayed their migration. In the 1950s, the dominance of men in the outflow returned. It has been argued that this was probably related to the contraction in male employment over the period. In a similar way, the 1960s saw a greater expansion in male employment and a rise in the female outflow again, relative to the male outflow. The 1960s was also a period during which restrictions on women's entry and continued presence in the labour force continued and this may have contributed to the greater female outflow. The net inflow of the 1970s contained a relatively higher number of males. The 1980s male outflow was again employment related in that, like the 1950s, the numbers of male job loses was greater than the number of female job loses.

Age

In order to see the age distribution of the net migration, consider Table 3.

\section{Table 3 here}

For most of the periods of net outflows, it can be seen that the outflow is concentrated in the 15-24 year age category and so emigration is a young person's pursuit. In the 
1950s, however, during a period of very depressed economic activity, the numbers emigrating in the 25-34 age category were almost equal to those in the 15-24 age band. Another noteworthy point arises in the 1960s. Even though there is a net outflow, it can be seen that there was an inflow of those in the 35-44 age band and in the $0-14$ age band. What this points to is older emigrants returning with families. This is seen more strongly in the 1970s; the net inflow is made up of the very young (0-14) and those over 35 . We also see in the 1970s that even in a period of net inflow, emigration was an option still being exercised by those in the 15-34 age group.

\section{Education/Occupation}

In spite of its obvious relevance from a national economic viewpoint, for many years there was practically no systematic information on the occupational and social structure of the net outflow. However, O'Gráda and Walsh (1994) make the point that the scale of emigration in the 1940s and 1950s was sufficiently large as to make it broadly representative of society at large. As such, many of the emigrants in this period would have been rural and unskilled. This is borne out by figures from the 1940s which show that 73 percent of the male emigrants were in either agricultural or unskilled occupations, while 57 percent of the female emigrants were in domestic service (Commission on Emigration, 1956).

O'Gráda and Walsh (1994) also argue that the change in the structure of occupations between 1946 and 1971 point to a continued outflow that was largely unskilled. Most of the contraction in employment over this period occurred in low-income occupations. As the level of unemployment did not increase in this period, it appears 
highly likely that those who would have occupied low skilled jobs in Ireland, had they been available, emigrated.

With rising levels of educational attainment in Ireland in the late 1960s and 1970s, an emigrant stream that was representative of society would have shown increasing skill levels. An analysis of the social-group make-up of the gross outflow in 1987-88 provided evidence that the outflow was indeed representative of Irish society (NESC, 1991, based on data from the Labour Force Survey of 1988). This analysis was based on the social group of the emigrant's head of household and so did not address directly the skill level of the emigrants themselves. In order to find some evidence on this point, we can look at Table 4 which is taken from O'Gráda and Walsh (1994).

\section{Table 4 here}

From this table we can see that in the 1980s the proportion emigrating of those who have acquired a third level qualification is higher than the proportion emigrating who leave school after second level. As such, there is evidence that the outflow may have become selective of the more highly skilled in the 1980s, thus altering the character of Irish emigration. Two qualifying points should be made. First, it could be that the second level school leavers may emigrate after a period of time has elapsed, whereby they may not have been captured in the numbers shown in Table 4. Second, although a high proportion of graduates may have emigrated in the 1980s, there is a belief that many of them ultimately returned thus reducing concerns about the extent to which Ireland was experiencing a "brain drain".

To summarise, in the earlier part of the century Irish emigrants were most likely to go to the United States; however, from 1930 onwards, Britain became the primary 
destination. Over time, there has been a balance between the proportions of males and females emigrating, although in certain sub-periods, there have been imbalances. Emigrants have typically been in the 15-24 year age bracket, although at times of particular economic depression older individuals have left also. Finally, whereas before the 1970s emigrants would have been largely unskilled, reflecting the population in general, emigration in more recent years has been more skilled in nature. This is partly because of improved educational levels in Ireland, but it may also be because emigration became more selective of the better educated ${ }^{3}$.

\section{The Factors behind the Migration Flow}

From the previous section it is clear that Ireland has experienced significant population outflows for many decades. In this section, we will look at the factors which have generated this outflow. Taking a broad overview, NESC (1991) identified a number of factors which combined to produce the outcome. For much of the twentieth century, Ireland's economic development lagged behind that of other countries. Ireland also had a relatively high birth which put pressure on labour supply. Irish people had ready access to the United States in the earlier part of the century and continue to have ready access to Britain. They have also had a network of previous emigrants who could ease the transition to life in the destination country. Given the combination of these circumstances, it is not surprising that the outflow occurred.

NESC (1991) and others have taken a more rigorous look at the factors which have generated the migration stream and it is to these studies that we now turn. The studies

\footnotetext{
3 The higher education levels of more recent Irish emigrants will be seen again in Section 4 when the characteristics of Irish people in their destinations are considered. The 'education selection' effect will
} 
in this area can be broken into two types, those which have viewed the issue from a macro perspective and those which have pursued a micro perspective. We will consider each group, and the lessons derived from them, in turn.

\section{A. Macro-studies}

To be precise, the studies in this sub-section are generally concerned with the determinants of year-to-year fluctuations in net migration and not with migration determinants per se. They all show that the Irish and British labour markets are closely linked because of the migration mechanism and focus on how migration responds to differences in labour market conditions between Ireland and Britain. Clearly, it is also the case that labour market conditions in Ireland would have responded to migration so in a sense the focus of the studies is incomplete. In Section 5 below, the issue of how migration affected Ireland will be considered.

An early study of the determinants of year-to-year fluctuations in Irish migration is that of Walsh (1974). The general approach adopted by Walsh in this paper has been followed by others so it is useful to outline the approach in some detail. His starting point is a model of the following form:

$M_{i j t}=\alpha+\beta_{1} Y_{i t}^{*}+\beta_{2} Y_{j t}^{*}$

$M_{j i t}=\alpha^{\prime}+\beta_{1}^{\prime} Y^{*}{ }_{i t}+\beta_{2}{ }^{\prime} Y^{*}{ }_{j t}$

$N_{i j t}=\left(\alpha-\alpha^{\prime}\right)+\left(\beta_{1}-\beta_{1}^{\prime}\right) Y^{*}{ }_{i t}+\left(\beta_{2}-\beta_{2}\right) Y_{j t}^{*}$

where $M_{i j t}$ is the gross migration flow from country $i$ to country $j$ in period $t, N_{i j t}$ is the net flow between the two countries and $\mathrm{Y}^{*}{ }_{\text {it }}$ is a measure of the expected lifetime

also been seen again, in Section 3, part B, when studies looking at the determinants of emigration are explored. 
income that would accrue to an individual in location i. Equation (3) can therefore be interpreted as saying that the net migration flow will depend on relative labour market conditions in the two countries.

Walsh's purpose was to establish how best to estimate a reduced-form model of the type described by Equation 3. In particular, he was interested in establishing if the expected income terms should be entered as ratios, levels or differentials and how the expected income term should be specified. For current purposes, however, our interest arises from what his results say about Irish migration.

Walsh estimated various forms of Equation (3) using data on the net migration flow from Ireland and wage and unemployment data from Ireland and Britain for the period 1951 to 1971 . While some of the net migration flow may not have been to or from Britain, it will be remembered from Section 2 that the vast bulk of emigration during this period was to that destination. His results show that Irish net migration was responsive to relative labour market conditions in Ireland and Britain, with both wage differentials and unemployment differentials appearing to be significant in the estimated equations.

The empirical approach in Walsh (1974) suffered from a particular weakness. The net migration equations were estimated using ordinary least squares; however, as mentioned in the paragraph introducing this sub-section, it is most improbable that variables such as Irish wages and Irish unemployment were exogenous. In order to overcome this problem, it would be necessary to estimate the net migration as part of a simultaneous system. Geary and McCarthy (1976) present an early attempt to do 
this. In this paper, Geary and McCarthy are attempting to develop an econometric model of price and wage inflation in a small open economy. They include a migration equation in their system and estimate it using Irish data from the period 1951 to 1971. The results of their estimation are similar to Walsh's in that net migration responds to differences in the unemployment rate between Ireland and Britain and to differences in wage rates.

While the papers of Walsh (1976) and Geary and McCarthy (1976) demonstrated that Irish net migration was responsive to relative labour market conditions in Ireland and Britain, it was subsequently shown that the migration equations which they had estimated suffered from instability and were not very useful in predicting migration flows. Keenan (1981) re-estimated the migration equations from these earlier papers, along with some specifications from other papers of this type, and uncovered this instability. Hence, although the link between the Irish and British labour markets had been established empirically, the task remained of refining the modelling of Irish migration.

One contribution to this migration equation specification issue is contained in the paper of Geary and O'Gráda (1989). The innovation introduced by them was to incorporate tax and welfare considerations into the expected income term. They define a variable, labelled the 'retention ratio', as follows:

$R E T_{i}=U R_{i \cdot} R R_{i}+\left(1-U R_{i}\right)\left(1-t_{2 i}\right)\left(1-t_{1 i}\right)$

$\mathrm{UR}$ is the unemployment rate, $\mathrm{RR}$ is the replacement rate, $\mathrm{t}_{2}$ is the employee social insurance contribution rate and $t_{1}$ is the income tax rate. RET is therefore the expected proportion of a pound of gross income retained by the individual. Expected income is 
then defined as RET multiplied by average earnings. The ratio of UK to Irish expected income (labelled RELY) is then entered into the migration equation, as follows:

$M=b_{0}+b_{1} R E L Y+b_{2} M(-1)$

where $\mathrm{M}(-1)$ is the lagged dependent variable.

Geary and O'Gráda concluded that the estimation of an equation specified in the manner just described generated a "strong, well-behaved and stable relationship". While this element of their work was later called into doubt (see below), they nonetheless uncovered a dimension to the Irish migration story which was of considerable importance in the 1980s, i.e. the tax and welfare dimension (again, see below).

The most recent attempt at estimating migration equations is in O'Gráda and Walsh (1994) so we will present their results:

\section{Table 5 here}

The dependent variable used is once again aggregate net migration. WDIFF and UEDIFF are the gaps between Irish and UK wages and unemployment rates. In specification (4), an alternative wage gap term is used, HTWDIFF, which is defined as follows: [WIR(1 - URIRL) - WUK (1- URUK)]. A dummy variable is also included to capture the years in which there was net inward migration (DUM70S); $\mathrm{T}$ is a time trend. All but one of the equations is estimated over ther period 1953 to 1990 . The results show again how Irish migration is determined by relative labour market conditions. They also show that the unemployment term is more precisely estimated and that the elasticity associated with the unemployment coefficient is greater than that of the wage coefficient. Finally, they re-estimated equations of the Geary and 
O’Gráda (1989); from their results it appears that the more traditional specifications perform better.

The problem identified by Keenan (1981) remains in that estimated migration equations continue to perform poorly in predicting the migration flow. Nevertheless, in building macro-models of the Irish economy, the crucial importance of including a migration equation is still argued (Barry and Bradley, 1991). The migration mechanism is a core element of the functioning of the Irish economy and so any attempt to provide an overview of the working of the economy must include migratory considerations. As menioned above, in Section 5 the wage/unemployment/migration link will be returned to when the effect of emigration on Irish wages and unemployment rates are assessed.

\section{B. Micro-studies}

A regularly recurring theme in the literature on Irish migration is the lack of data on those who left. Hence, in trying to gain insights into the mass exodus from the perspectives of the individuals who left, the sources are extremely thin. A handful of studies do, however, exist and so we will distil the lessons from them.

The most comprehensive study of the migratory decisions in the 1960s is that of Hannan (1970). In 1965, Hannan set about interviewing over 500 young people in a rural part of Ireland. The area selected was typical of many rural areas at the time in that it had experienced significant outflows over a long period. The young people were selected in such a way that they were at a stage where they had begun to think about their futures and whether they would remain in the area or not. They were asked 
a range of questions which sought to ascertain such things as their attitudes to their community, their ambitions and aspirations, along with background characteristics such as social class, parents' education levels etc.

Hannan's first task was to establish links between a range of variables and an intention to migrate. He found that one of the strongest generators of an intention to migrate was a belief that occupation and income aspirations could not be satisfied in the community in question. He also found that alienation from the local community lead to an intention to migrate but that family obligations reduced the likelihood of planned migration.

In 1968, Hannan conducted a follow up survey. His primary motivation was to assess the extent to which the intentions which people had expressed in 1965 had been translated into action. The data set which was generated was subsequently analysed by O'Gráda (1986) who estimated logit regressions with a dependent variable indicating whether the individual had emigrated or not. The analysis produced a number of results which include the following. Education had a positive effect on the likelihood of emigration. Similarly, the existence elsewhere of family members who could assist in the transition to a new environment also increased the likelihood of emigration. The father's occupation appeared to work as a proxy for family wealth and tended to be negatively related to the likelihood of emigration. Finally, a variable which captured the mother's attitude to migration was also found to increase the probability of emigration. While there may be an element of ex-post rationalisation being captured by this effect, O'Gráda concludes from this result and other pieces of evidence that there was an important element of joint decision making in regard to emigration. 
While much migration modelling focuses on the costs and benefits to the individual, such a framework does not appear to be adequate for the emigration being analysed here.

A more recent analysis of individual migration decisions is contained in NESC (1991). The sample used in this study was drawn from the group who left secondary school in 1982. The group were first interviewed in May 1983; they were then reinterviewed in November 1984 and yet again between November 1987 and February 1988. For some of the analysis an extra group from the 1981 cohort of school leavers who had entered third level were added; the full sample amounted to 1990. From Section 2, it will be recalled that the 1980s were a period of heavy outmigration and so this sample were able to tell much about the nature of migration in this important period.

One of the clear findings was that emigration was strongly linked to education. Again, this is something that arose in Section 2; the outmigration from Ireland in the 1980s appears to have been selective of the better educated. The likelihood of emigration was also found to be positively associated with socio-economic status, where this was measured using an index which accounted for variables such as father's occupation and level of education. Those who came from more remote areas were also more likely to emigrate. In contrast, the group that were least likely to emigrate were the less educated, working-class, urban youth.

Another interesting issue uncovered in NESC (1991) is that much of this emigration was not a function of joblessness; rather it was related to underachievement in the 
labour market in the sense that those with various levels of education were not able to find positions in which their skills were fully used. The picture that emerged was of a type of emigration whereby better educated individuals were using this option as part of a general career strategy. It has been shown that in Ireland in the 1980s a significant degree of "trading down" occurred. The job market was sufficiently weak that employers were able to fill positions with individuals of ever increasing qualifications (Breen, 1984). They may also have been responding to tax related incentives, as the Irish tax system became increasingly punitive in the 1980s (Callan and Sutherland, 1997). Hence, these individuals simply moved to Britain where they could use their skills more profitably. At the same time that this was occurring, however, there was still a group of very low-skilled individuals emigrating.

The data used in NESC (1991) was also used by Reilly (1993) but he extended the analysis to look at the issue of return migration. In jointly modelling the decsion to migrate and subsequently to return, he finds weak evidence that the less educated are more likely to return while the more educated are more likely to stay away. However, he finds that the country to which the individuals emigrated has a stronger effect on the likelihood of return. In particular, those who emigrated to Britain were more likely to stay away than those who emigrated to the United States or to mainland Europe. While the absense of large Irish communities in mainland Europe relative to Britain, plus language difficulties, may explain the higher rate of return migration from there, the rate of return migration from the United States is less readily explained. One possible explanation is that much of the Irish emigration to the United States in the 1980s was illegal in nature; hence, the emigrants may not have viewed their migration as a longterm choice. 
Before leaving the area of studies into the decisions of individuals to migrate, we will draw on a sociological qualitative study of the group of 1980s Irish emigrants just mentioned, those who worked illegally in the United States. Corcoran (1993) observed this group and sought to discover, amongst other things, why they had left Ireland. In so doing she provides an interesting insight into the migration motives of this group. She develops a three way classification of motivations and we mention it here by why of highlighting the issues which were driving the large-scale emigration of the 1980s. One of her groups is labelled the "bread and butter" emigrants. These are people who were unemployed in Ireland before leaving or could only find small amounts of work. A second group is labelled the "disaffected adventurers". These were people who were employed in Ireland but who saw there career advancement as being severely limited in the Ireland of the 1980s and who viewed the tax system as being overly harsh. These appear to be the group that NESC (1991) uncovered and which were discussed above. The final group is labelled the "holiday-takers; these are people from relatively wealthy backgrounds who were treating the stay in the United States as merely a working holiday.

The most important summary point to be taken from this sub-section is that in the 1980s it appears that the more educated were leaving. This was possibly due to taxation and to the 'trading down' which was occuring whereby higher qualifications were required for lower positions due to the very poor state of the labour market. Given the Reilly (1993) finding that the less educated were more likely to return, the possibility of a 'brain drain' seemed quite real. However, it is possible that the economic boom which Ireland is currently enjoying is leading to a net inflow which is 
made up of the more highly educated than the population in general. Drawing on information from the Labour Force Surveys of the mid-1990s, in which those who have returned to Ireland in the previous twelve months are identified, Barrett and Trace (1998) show that the 'returners' do have higher educational attainment and higher occupational levels than the population in general.

\section{The Irish Away}

Many studies in the economics of migration explore the issue of how well immigrants assimilate into their new environments. In the Irish context, what is of greater interest is how Irish emigrants fared in their destinations. Unfortunately, there are very few studies to our knowledge that consider this issue is a manner that satisfactorily explores the idea of assimilation. Generally what has been done is simply to take a snap-shot of the Irish in Britain and to compare them to the British population. While this tells us something about the standing of the Irish immigrant community in Britain, it tells us nothing about the assimilation of Irish individuals over time. Nevertheless, we will discuss these studies and distil the information that does exist.

Hughes and Walsh (1976) drew on information in the UK census of 1971 and on special tabulations compiled by the UK Office of Population Censuses and Surveys in 1971 to document the occupational, industrial and socio-economic structure of Irish emigrants in Britain. Their work focused on those who had arrived in Britain in the previous year and in the previous five years; as such, the group they were looking at were relatively recent arrivals and so while the data presented tell us something about entry level positions, they tell us less about assimilation as such. 
For male emigrants, the picture to emerge is that of concentration in a number of occupations, industries and socio-economic groups. A third of them were 'construction workers' or 'labourers n.e.c.', a finding which confirms the stereotype of the Irish construction worker in Britain. Nearly 60 percent were in the skilled, semiskilled and unskilled manual socio-economic groups. This impression of the Irish males in Britain corresponds with the impression of those who were leaving at the time, as discussed in Section 2 above. For females, the occupational distribution uncovered reveals a higher occupational status for Irish women in Britain than for Irish men. In addition, while it was shown using chi-square tests that both Irish men and Irish women in Britain had different occupational distributions than the British labour force, the female distributions were closer than the males. It was also shown that the occupational distribution of those who had been there longer was closer to that of the British, so this amounts to some evidence of assimilation.

A more recent study of the Irish in Britain is that of Hornsby-Smith and Dale (1988). The angle of the assimilation issue which they consider is how well the second generation do relative to the first generation. They take their data from General Household Survey's of 1979 and 1980 and look at those who were born in the Republic of Ireland (the first generation), those born in Britain but with at least one Irish parent (the second generation) and those born in Britain of British parents (the native population).

Like the other work which has been discussed already, they observe first generation Irish men to be more heavily represented in the semi-skilled and unskilled socioeconomic categories than their British counterparts. Irish women, however, appear to 
have higher education levels and a higher occupational status. It is also observed that the Irish experience a good degree of social mobility between the first and second generations; in terms of educational attainment, the second generation Irish have levels of attainment that are at least as high as their British counterparts. What is perhaps of greater interest from this paper, however, is the contrasting experiences of second generation Irish people from the Republic and from Northern Ireland. While those from the Republic experience upward mobility across the generations, those from Northern Ireland experience downward mobility.

A more recent study of this type is contained in NESC (1991). A number of sources are drawn upon to generate information on the Irish in Britain. The British Labour Force Surveys from 1985 to 1987 are used to establish the occupational distribution of the Irish relative to the British and a number of interesting findings emerge. Like earlier studies, the Irish are seen to be more heavily concentrated in the lower ends of the socio-economic distribution. But based on remarks made already in this chapter on the changing nature of the emigrant outflow, it is not that surprising that a different picture emerges if the Irish are looked at by age group. It is shown that the occupation attainment level of the Irish aged 16-24 had improved relative to the older generation of Irish immigrants. (This is also found in Halpin (1997) where he uses British Labour Force Surveys from 1994, second quarter, to examine the characteristics of the Irish in Britain.) However, there is also evidence that some Irish people are not doing as well as they might expect given their educational levels. The conclusions drawn are as follows: Irish third-level graduates are getting into occupations appropriate to their levels of education; however, those with second level education are not achieving 
occupation level that might be expected of them. NESC (1991) also report the type of second generation assimilation found by Hornsby-Smith and Dale (1988).

Again distilling an important summary point, the view of the Irish abroad corresponds with what would be expected, given what we have already described when discussing who left. In particular, the nature of Irish emigration appears to have changed in that modern day Irish emigrants are more educated than was previously the case. Before leaving the issue of the Irish abroad, it is interesting to briefly consider how the Irish in the United States have fared. Perhaps because the United States has declined in importance for Irish emigrants, there appears to be little recent work devoted specifically to the Irish in there. However, Reilly (1993) offers some discussion based on Borjas (1987). Borjas finds that the Irish do considerably less well than immigrants from the U.K.. Given the lower skill levels of earlier cohorts of Irish emigrants, this is perhaps not surprising. However, Borjas also finds that there is little difference between Irish emigrants from the 1950s and the 1970s, relative to U.S. natives, and this is surprising.

\section{The Effects of Large-scale Emigration}

Many writers on the Irish economy took the view that the large-scale emigration of most of this century was not only a symptom of economic failure but also a cause. A number of arguments have been put forward to support this view. Among them are the following: emigration reduced the size of the domestic market and thus reduced opportunities to avail of economies of scale; emigration robbed the country of the brightest and the best; the outward flow reduced the urgency of achieving higher growth rates. 
An alternative and more positive view of emigration would see emigration as contributing to a convergence between Irish living standards and those elsewhere, as a shifting labour supply curve moved along a labour demand curve. It has been pointed out that had net migration been zero in the post-war years, the population of the Republic of Ireland would have been between a quarter or a third larger than it now is. It is hard to imagine that the additions to the labour force implied by such population estimates would not have had a depressing effect on wages and/or would not have increased unemployment. A number of studies have attempted to uncover empirical evidence on the issue of how emigration effected variables such as wages and unemployment and so we now consider these.

There appears to have been convergence between Irish and British wages in the latter part of the nineteenth century and early twentieth century (O'Rourke, 1995; Boyer, Hatton and O'Rourke, 1994). Given the relative failure of Ireland to industrialise at that time, the authors on this topic attribute the relative Irish wage growth to emigration. There is some disagreement, however, over where Irish wages stood relative to British wages between the 1930s and the 1960s. O'Rourke (1994) shows, using data from the International Labour Organisation, that in three industries (building and construction, engineering, and printing and publishing) Irish wages were actually higher than British wages in the years 1926 to the mid-1980s, except for a period between 1952-1964 during which relative Irish wages collapsed. This prompts him to ask if 'labour flowed uphill' and the chapter contains some possible explanations of the apparent paradox. 
A recent paper by Curtis and Fitzgerald (1996) presents a somewhat different view of relative wages in Ireland and Britain, at least as far as relative levels are concerned. Using data on industrial wages from the Central Statistics Office which are more broadly based than the data used by O'Rourke, they show that the ratio of Irish industrial wages relative to those in Britain was only around 75 percent in 1930. The ratio then fell to around 60 percent at the beginning of the War and then rose again after the war. These movements in the ratio are consistent with those presented in O'Rourke (1994), as is the fall in relative Irish wages in the 1950s. However, according to Curtis and Fitzgerald, a convergence in wages between Ireland and Britain began in the early 1960s, with the Irish/British wage ratio rising from around 60 percent in 1960 to 95 percent in the late 1970s. The ratio then hovered around the 95 percent mark until 1990.

Given the broader nature of the data in Curtis and Fitzgerald paper relative to those used by O'Rourke, it is possible that while wages were higher in the industries O'Rourke considered, this was not generally true. Hence, labour may not have 'flowed uphill'. O'Gràda and Walsh (1994) have suggested that there may have been entry barriers to the high-wage occupations identified by O'Rourke; hence the relevant wages facing Irish emigrants were indeed lower in the Ireland than in the U.K. However, a question that remains from the Curtis and Fitzgerald paper is why the convergence occured after 1960 and not between 1930 and 1960. Curtis and Fitzgerald suggest that the opening of the Irish economy in the 1960s contributed to the convergence in wages but the mechanism remains unclear. They conclude with the point that U.K. wages play a important role in determining Irish wages. 
With respect to unemployment, two papers have suggested that net migration may have had the effect of creating a stable differential between Irish and British unemployment rates. In the first of these papers, Honohan (1984) makes the point that most studies that have looked at the links between the Irish and British labour markets have done so through the types of migration equations discussed in Section 3. As these suffer serious data problems, he sees an advantage in simply looking at Irish and UK unemployment rates. He maintains that closely related movements in the two rates are at least consistent with a story which says that in times of high UK unemployment, Irish emigrants return home or chose not to move, thus increasing Irish unemployment. Similarly, as UK unemployment falls, emigration resumes and the Irish unemployment problem eases. His empirical work indicates that Irish unemployment did indeed react to movements in British unemployment and that over time, Irish unemployment would converge to an equilibrium relationship with UK unemployment whereby it stood at 5 percent above the UK level.

This issue was re-visited by Honohan (1992) using data up to the last quarter of 1991. While arguing that UK unemployment still has a strong influence on Irish unemployment, he believes that the equilibrium gap is no longer constant and had risen. He suggests that the reduced strength of the link may be a result of a growing group of long-term unemployed in Ireland who do not form part of a once mobile labour force and who instead remain in Ireland even if unemployed.

In discussing the effect of emigration on wages and unemployment separately, the impression is incorrectly given that the effects are determined separately. This is of course untrue; as mentioned in Section 3 above, migration, unemployment and wages 
are all jointly determined. The fact that the studies have been presented here in this disjoint way reflects the way in which our understanding in the area has been advanced and also that a need for a more comprehensivce understanding remains.

Before leaving this area, we will consider two additional studies. In spite of the importance of emigration in the Irish macroeconomic experience and the questions it gives rise to in terms of effects, there are only a limited number of studies which have tested with any degree of rigour what the effects might have been. Walsh (1989) attempts to assess the degree to which there may have been a causal relationship which ran from high net out migration to low growth in GNP. He employs the Sims' (1972) time series tests for causality, using data on Irish net migration and real GNP per capita from the period 1948 to 1987 . While he finds there to be evidence that GNP affected net migration, no evidence is found for the reverse affect. Hence, the argument that net migration retarded GNP growth is not supported. On a much more informal level, it has been pointed out that the huge outflow of the 1950s did not appear to impede growth in the 1960s; likewise, the population inflows of the 1970s preceded the economic stagnation of the 1980s. Thus, there is further doubt surrounding the negative view of emigration.

Some additional insights into the impact of migration on the economy can be gained from an exercise reported in NESC (1991). Using the HERMES-Ireland model of the macroeconomy (details of which are reported in Bradley et al 1989), a simulation was conducted that estimates the impact of a rise in UK unemployment of 4 percent. Such a rise would reduce Irish emigration and this effect is captured by the migration equation in the model. The impacts on a range of macroeconomic variables five years 
after the event are estimated. It is estimated that net emigration would fall by 35,000 and the unemployment rate would rise by 2.6 percentage points. While real GDP would rise by 0.9 percent, GDP per capita would fall by 2.8 percent. Hence, the migration fall would reduce living standards in Ireland.

\section{Summary and Conclusion}

The purpose of this chapter has been to establish what we know about Irish migration. We can summarise our knowledge as follows. For most of its recent history, Ireland has experienced net outward migration. A number of factors have generated the conditions whereby such outward flows could be expected; these include the lower level of development of the Irish economy relative to elsewhere, the ready access which Irish people have had to other countries and the existence of networks of Irish emigrants which facilitated emigration. The year to year fluctuations have been affected by relative labour market conditions in Ireland and Britain so it appears that Irish people were reacting to economic stimuli when migrating. This is borne out by studies of the decision to migrate in which it has been shown that lack of a job, or of a satisfactory job, lead to emigration.

Up until the 1960s, the emigration flow seemed to be broadly representative of Irish society; the result of this was that many emigrants were relatively unskilled. With improving educational standards in Ireland since the late 1960s, an outflow that was broadly representative of society would have shown an increased level of education. However, there is evidence to show that this effect was added to by emigration that was somewhat selective of the more educated in the 1980s. 
The nature of the outflow from Ireland is reflected in the characteristics of the Irish when viewed abroad. It had previously been the case that the Irish in Britain were in lower occupational categories. However, more recent emigrants are located further up the occupational ladder. In addition, an amount of upward social mobility between first and second generation Irish appears to occur.

One of the main impacts of emigration on the Irish labour market has been to reduce unemployment. While there is evidence that wage convergence between Ireland and Britain occurred in the nineteenth century and early part of the twentieth century, such convergence is not evident between the 1930 and 1960. After 1960, convergence seems to have re-emerged and there is now a close link between movements in Irish and British wages

Clearly, the Irish research on migration has been dominated by matters related to emigration. With the recent surge in economic growth, the net netward migration that was experienced in the 1970s has returned. The most recent figures show that between April 1996 and April 1997, there was net inward migration of 15,000. A substantial part of this would be made up of return migrants but there is a belief that a growing number are non-Irish born immigrants. Data on this is limited but one indication of the growing attractiveness of Ireland as a destination for immigrants is seen in the figures on asylum seekers. In 1990, there were 62 applications made; this figure had grown to 424 by 1995; in the first half of 1997, the figure around 2000.

So while much of what we know about Irish migration relates to the net outward flow, it appears that the research requirements in the coming years will be more like those 
of the core EU countries and the U.S.. At the first stage, it will be important to know the characterisitcs of the inflow, be they returning migrants and immigrants. It will also be important to know what the effects of immigrants and returning migrants are on wages and employment. And over time, we will want to know how well immigrants assimilate. In sum, the research agenda on migration for Ireland in the late 1990s and early 2000s will be that be of the established immigration countries. 
Table 1: Components of population change in intercensal periods, 1871-1996

\begin{tabular}{|c|c|c|c|}
\hline $\begin{array}{l}\text { Intercensal } \\
\text { Period }\end{array}$ & $\begin{array}{c}\text { Population } \\
\text { Change }\end{array}$ & $\begin{array}{c}\text { Natural Increase } \\
\text { (i.e., births less deaths) } \\
\text { Annual Averages }\end{array}$ & $\begin{array}{c}\text { Net } \\
\text { Migration }\end{array}$ \\
\hline $1871-1881$ & $-18,317$ & $+31,855$ & $-50,172$ \\
\hline $1881-1891$ & $-40,133$ & $+19,600$ & $-59,733$ \\
\hline 1891-1901 & $-24,688$ & $+14,954$ & $-39,642$ \\
\hline 1901-1911 & $-8,214$ & $+17,940$ & $-26,154$ \\
\hline 1911-1926 & $-11,180$ & $+15,822$ & $-27,002$ \\
\hline 1926-1936 & -357 & $+16,318$ & $-16,675$ \\
\hline 1936-1946 & $-1,331$ & $+17,380$ & $-18,711$ \\
\hline 1946-1951 & $+1,119$ & $+25,503$ & $-24,384$ \\
\hline 1951-1961 & $-14,226$ & $+26,652$ & $-40,877$ \\
\hline 1961-1971 & $+15,991$ & $+29,442$ & $-13,451$ \\
\hline 1971-1981 & $+46,516$ & $+36,127$ & $+10,389$ \\
\hline 1981-1991 & $+8,231$ & $+28,837$ & $-20,606$ \\
\hline 1991-1996 & $+19,062$ & $+18,426$ & +637 \\
\hline 1996-1997 & $+44,000$ & $+29,000$ & $+15,000$ \\
\hline \multicolumn{4}{|c|}{ Rates per 1,000 average population } \\
\hline $1871-1881$ & -4.6 & +8.0 & -12.7 \\
\hline $1881-1891$ & -10.9 & +5.3 & -16.3 \\
\hline 1891-1901 & -7.4 & +4.5 & -11.9 \\
\hline $1901-1911$ & -2.6 & +5.6 & -8.2 \\
\hline 1911-1926 & -3.7 & +5.2 & -8.8 \\
\hline 1926-1936 & -0.1 & +5.5 & -5.6 \\
\hline 1936-1946 & -0.4 & +5.9 & -6.3 \\
\hline $1946-1951$ & +0.4 & +8.6 & -8.2 \\
\hline 1951-1961 & -4.9 & +9.2 & -14.1 \\
\hline $1961-1971$ & +5.5 & +10.2 & -4.6 \\
\hline $1971-1981$ & +14.5 & +11.3 & +3.2 \\
\hline 1981-1991 & +2.4 & +8.3 & -5.9 \\
\hline 1991-1996 & +5.3 & +5.2 & +0.2 \\
\hline 1996-1997 & +12 & +8 & +4 \\
\hline
\end{tabular}

Sources: $1871-1996$ taken from Sexton, 1996; 1996-1997 taken from Central Statistics Office (1997). 
Table 2: $\quad$ Net Migration by Sex 1871-1986

\begin{tabular}{|c|c|c|c|c|}
\hline \multirow[t]{2}{*}{$\begin{array}{c}\text { Intercensal } \\
\text { Period }\end{array}$} & Males & Females & Persons & \multirow[t]{2}{*}{$\begin{array}{c}\text { No. offemales } \\
\text { per 1,000 males }\end{array}$} \\
\hline & \multicolumn{3}{|c|}{ Annual Average ('000) } & \\
\hline $1871-1881$ & $-24,958$ & $-25,314$ & $-50,172$ & 1,010 \\
\hline 1881-1891 & $-29,257$ & $-30,476$ & $-59,733$ & 1,042 \\
\hline 1891-1901 & $-20,315$ & $-19,327$ & $-39,642$ & 951 \\
\hline 1901-1911 & $-11,764$ & $-14,390$ & $-26,154$ & 1,223 \\
\hline 1911-1926 & $-13,934$ & $-13,068$ & $-27,002$ & 938 \\
\hline 1926-1936 & $-7,255$ & $-9,420$ & $-16,675-$ & 1,298 \\
\hline 1939-1946 & $-11,258$ & $-7,453$ & $-18,711$ & 662 \\
\hline 1946-1951 & $-10,309$ & $-14,075$ & $-24,384$ & 1,365 \\
\hline 1951-1961 & $-21,786$ & $-19,091$ & $-40,877$ & 876 \\
\hline 1961-1971 & $-6,236$ & $-7,215$ & $-13,451$ & 1,157 \\
\hline 1971-1981 & $+5,806$ & $+4,583$ & $+10,389$ & 789 \\
\hline 1981-1986 & $-8,283$ & $-6,094$ & $-14,377$ & 736 \\
\hline 1986-1991 & $-14,820$ & $-11,920$ & $-26,740$ & 804 \\
\hline
\end{tabular}

Source: $1871-1986$ taken from NESC (1991); 1986-1991 from Sexton (1996) 
Table 3: $\quad$ Net Migration Classified by Age for Intercensal Periods Between 1946 and 1986

\begin{tabular}{|c|c|c|c|c|c|c|}
\hline \multirow{2}{*}{$\begin{array}{l}\text { Persons } \\
\text { (at end of period) }\end{array}$} & $1946 / 51$ & $1951 / 61$ & $1961 / 71$ & $1971 / 81$ & $1981 / 86$ & $1986 / 91$ \\
\hline & \multicolumn{6}{|c|}{$(\cdot 000)$} \\
\hline $0-14$ & -4.4 & -22.9 & +23.1 & +47.4 & -6.3 & -9.3 \\
\hline $15-24$ & -66.3 & -146.9 & -90.8 & -10.2 & -48.5 & -105.3 \\
\hline $25-34$ & -43.6 & -140.0 & -64.7 & -1.1 & -19.1 & -35.1 \\
\hline $35-44$ & -8.1 & -44.5 & +8.1 & +39.6 & -1.6 & \\
\hline $45-64$ & -3.7 & 54.3 & -15.8 & +9.8 & -2.9 & -1.2 \\
\hline $65+$ & +9.6 & +11.5 & +7.3 & -18.2 & +6.5 & -7.4 \\
\hline Total & -116.6 & -397.1 & -132.8 & +103.7 & -71.9 & -133.7 \\
\hline
\end{tabular}


Table 4: $\quad$ Percentage Emigrating of Second- and Third-Level Education Leavers

\begin{tabular}{|c|c|c|c|}
\hline \multirow[b]{2}{*}{ Year of Leaving } & \multirow[b]{2}{*}{ Second Level } & \multicolumn{2}{|c|}{ Third Level } \\
\hline & & Primary Degree & Higher Degree \\
\hline 1980 & 1.7 & 8.0 & 17.0 \\
\hline 1981 & 1.1 & 7.6 & 21.9 \\
\hline 1982 & 1.8 & 8.1 & 18.8 \\
\hline 1983 & 3.5 & 9.4 & 15.3 \\
\hline 1984 & 4.1 & 14.3 & 19.4 \\
\hline 1985 & 5.7 & 16.2 & 27.1 \\
\hline 1986 & 6.1 & 19.5 & 24.4 \\
\hline 1987 & 10.5 & 25.6 & 28.9 \\
\hline 1988 & 14.7 & 26.1 & 27.6 \\
\hline 1989 & 9.9 & 24.9 & 30.8 \\
\hline 1990 & 8.1 & 19.0 & 24.1 \\
\hline
\end{tabular}


Table 5: Accounting for the Variation in Irish Emigration

\begin{tabular}{|c|c|c|c|c|c|c|c|}
\hline & \multicolumn{7}{|c|}{ Equation Number } \\
\hline & (1) & (2) & (3) & (4) & (5) & (6) & (7) \\
\hline \multirow[t]{2}{*}{ Constant } & 6.382 & 6.091 & 7.987 & 14.041 & 6.192 & 4.597 & 3.749 \\
\hline & $(2.00)$ & $(1.75)$ & $(2.10)$ & $(8.87)$ & $(1.05)$ & $(2.79)$ & $(1.41)$ \\
\hline \multirow[t]{2}{*}{ WDIFF } & -0.081 & -0.062 & -0.202 & - & -0.005 & - & -1.45 \\
\hline & $(-0.70)$ & $(-0.49)$ & $(-1.22)$ & $(-0.02)$ & $(-1.36)$ & - & - \\
\hline HTWDIFF & - & - & - & -0.0029 & - & - & - \\
\hline \multirow[t]{2}{*}{ UEDIFF } & 1.814 & 1.851 & 1.467 & - & 1.775 & 2.156 & 0.987 \\
\hline & $(2.67)$ & $(2.53)$ & (1.85) & $(1.65)$ & $(5.87)$ & (1.95) & $(-4.64)$ \\
\hline \multirow[t]{2}{*}{ DUM70s } & -9.503 & -9.292 & -7.800 & -8.634 & - & -9.472 & -7.951 \\
\hline & $(-7.93)$ & $(-6.84)$ & $(-4.40)$ & $(-6.01)$ & $(-7.34)$ & $(-7.92)$ & - \\
\hline \multirow[t]{2}{*}{$T$} & -0.422 & -0.417 & -0.533 & -0.592 & -0.499 & 0.363 & -0.244 \\
\hline & $(-3.94)$ & $(-3.27)$ & $(-3.42)$ & $(-5.36)$ & $(-1.86)$ & $(-5.49)$ & $(-2.21)$ \\
\hline$R^{2}$ & .865 & .888 & .885 & .858 & .751 & .880 & .916 \\
\hline Method & OLS & $\operatorname{AR}(1)$ & $\mathrm{AR}(1)$ & $\mathrm{AR}(1)$ & $\operatorname{AR}(1)$ & $\mathrm{AR}(1)$ & OLS \\
\hline Period & $53-90$ & $53-90$ & $53-88$ & $53-90$ & $53-90$ & $53-90$ & $62-86$ \\
\hline D-W & 1.31 & 2.28 & 2.27 & 1.96 & 2.03 & 2.34 & 1.79 \\
\hline
\end{tabular}

Sources: $\quad$ Taken from O'Gráda and Walsh (1994). 


\section{References}

Barrett, A. (1996) 'The Greencard Lottery Winners: Are They More or Less Skilled than Other Immigrants?, Economics Letters, 52, 331-335.

Barrett, A. and F. Trace (1998) 'Return Migration to Ireland in the 1990s', mimeo, Economic and Social Research Institute, Dublin.

Barry, F. and J. Bradley (1991) 'On the Causes of Ireland's Unemployment', Economic and Social Review, 22, 253-286.

Bradley, J., J. Fitzgerald, D. Hurley, L. O’Sullivan and A. Storey (1989) HERMESIreland, A Model of the Irish Economy: Structure and Performance, Dublin: Economic and Social Research Institute.

Borjas, G.J. (1987) 'Self-Selection and the Earnings of Immigrants', American Economic Review, 77, 531-553.

Boyer, G.R., T.J. Hatton and K. O’Rourke (1994) 'The Impact of Emigration on Real Wages in Ireland, 1850-1914' in T.J. Hatton and J.G. Williamson (eds.) Migration and the International Labour Market 1850-1939, London: Routledge.

Breen, R. (1984) Education and the Labour Market: Work and Unemployment among Recent Cohorts of Irish School Leavers, Dublin: Economic and Social Research Institute, General Research Series Paper No. 119. 
Callan, T. and H. Sutherland (1997) 'Income Supports in Ireland and the UK', in T.

Callan (ed.), Income Support and Work Incentives: Ireland and the UK, Dublin: Economic and Social Research Institute, Policy Research Series Paper No. 30.

Central Statistics Office (1997) Population and Migration Estimates April 1997, Dublin: Central Statistics Office.

Commission on Emigration and Other Population Problems (1956), Report, Dublin: Government Publications Office.

Corcoran, M.P. (1993) Irish Illegals: Transients between Two Societies, Westport, Connecticut: Greenwood Press.

Curtis, J. and J.D. Fitzgerald (1996) 'Real Wage Convergence in an Open Labour Market', Economic and Social Review, 27, 321-340.

Geary, P.T. and C. McCarthy (1976) 'Wage and Price Determination in a Labour Exporting Economy: The Case of Ireland', European Economic Review, 8, 219-233.

Geary, P.T. and C. O’Gráda (1989) 'Post-war Migration between Ireland and the United Kingdom: Models and Estimates', in Gordon, I. and A.P. Thirlwall (eds.), European Factor Mobility: Trends and Consequences, London, MacMillan. 
Halpin, B. (1997) 'Who Are the Irish in Britain? Evidence from Large-scale Surveys' Working Papers of the ESRC Research Centre on Micro-social Change, Paper 97-15, Colchester: University of Essex.

Honohan, Patrick (1984) 'The Evolution of Unemployment in Ireland 1962-1983', in Baker, T., T. Callan, S. Scott and D. Madden (eds.), Quarterly Economic Commentary (May), Dublin: Economic and Social Research Institute.

Honohan, P. (1992) 'The Link between Irish and UK Unemployment', in Baker, T., S. Scott and S. Cantillon (eds.), Quarterly Economic Commentary (Spring), Dublin: Economic and Social Research Institute.

Hornsby-Smith, M.P. and A. Dale (1988) 'The Assimilation of Irish Immigrants in Britain', British Journal of Sociology, 39, 519-544.

Hughes, J.G. and B.M. Walsh (1976) 'Migration Flows between Ireland, the United Kingdom and the Rest of the World, 1966-71', European Demographic Information Bulletin, 7, 125-149.

Keenan, J.G. (1981) 'Irish Migration: All or Nothing Resolved?', Economic and Social Review, 12, 169- 186.

NESC (National Economic and Social Council) (1991) The Economic and Social Implications of Emigration, prepared for the Council by J.J. Sexton, B.M. Walsh, D.F. Hannan and D. McMahon, Dublin: National Economic and Social Council. 
O’Gráda, C. (1986) 'Determinants of Irish Emigration: A Note', International Migration Review, 20, 650-656.

O’Gráda, C. and B.M. Walsh (1994) 'The Economics Effects of Emigration: Ireland' in B.J. Asch (ed), Emigration and Its Effects on the Sending Country, Santa Monica, California: Rand.

O'Rourke, K. (1995) 'Emigration and Living Standards in Ireland since the Famine', Journal of Population Economics, 8, 407-421.

O’Rourke, K. (1994) 'Did Labour Flow Uphill? International Migration and Wage Rates in Twentieth Century Ireland' in G. Grantham and M. McKinnon (eds.) The Evolution of Labour Markets, London: Routledge.

Reilly, B. (1993) 'What Determines Migration and Return? An Individual Level Analysis Using Data for Ireland', University of Sussex, mimeo.

Sexton, J.J. (1997) 'Ireland', in Third Report for the OECD Continuous Reporting System on Migration (SOPEMI)', Paris: OECD.

Sims, C.A. (1972) 'Money, Income and Causality', American Economic Review, 42, $540-552$. 
Walsh, B.M. (1974) 'Expectations, Information, and Human Migration: Specifying an Econometric Model of Irish Migration to Britain', Journal of Regional Science, 14, 107-120.

Walsh, B.M. (1989) 'Tests for Macroeconomic Feedback from Large-scale Migration Based on the Irish Experience: A Note', Economic and Social Review, 20, 257-266. 